\title{
九州大学 先導物質化学研究所 複合分子システム分野
}

高 原 淳* · 大塚 英 幸* - 小林 元 康*

\section{1. 先導物質化学研究所}

先導物質化学研究所は, 機能性の高い物質 - 材料の創成 とその実用化基盤工学の構築にかかわる基礎化学からプロ セスエ学までの理工学分野の幅広い研究領域を包含した組 織であり, 平成 15 年 4 月 1 日に機能物質科学研究所と有 機化学基礎研究センターとを融合・再編成して新たに組織 された新しい研究所である。

先導物質化学研究所は, ナノテクノロジー, 情報科学, 環境・エネルギー, バイオ・ライフサイエンスなどの 21 世紀を支える先端的産業技術の礎として必要不可欠な, 「物 質化学における先導的な総合研究」を展開することを目的 としており, 有機化学・合成化学をベースに特徴ある機能 を発現する分子の開発，有機分子の超効率・高選択反応の 開発, 高度に制御した物質変換法を開発する物質基盤化学 部門, 原子・分子レベルの物質化学の未踏領域である, 原 子集合体 (クラスター), 分子集合体, 超分子の基礎化学 を確立し, 分子の構造, 電子構造の設計, 合成, 物性 - 反 応性の開拓, 機能性分子への応用を目指す分子集積化学部 門, 分子ナノテクノロジー, バルク材料の微細加工, 自己 組織化等の手法を駆使して有機一無機一バイオ, 炭素一有 機など従来の学問領域の境界に位置する融合材料の創成と 応用を目指す融合材料部門, 精密に構築された分子・原子 集合体の微細構造の計測と機能解析, 規則配列を実現する プロセスの開発を通じて, ナノ構造を有するバルク材料を 実現し, 先端デバイスの実現を目指す先端素子材料部門の 4 つの部門が連携して, 原子・分子・ナノスケールからマ クロスケールまでの物質の構造と機能にかかわる基礎学術 とその応用化に関する世界レベルの中核的研究拠点を形成 目指している（詳細はhttp：//www.cm.kyushu-u.ac.jp/ index-j.html をご参照ください).

\section{2. 分野の概要}

複合分子システム分野は, 分子集積化学部門に属し, 現 在, 高原 淳教授, 大塚英幸助教授, 小林元康特任助手に 加え, テクニカルスタッフ 1 名, 精密高分子プロジェクト 集中研研究員 2 名, 博士研究員 3 名, 博士課程 5 名 (社会

* Takahara, Atsushi/Otsuka, Hideyuki/Kobayashi, Motoyasu 九州大学 先導物質化学研究所 複合分子システム分野 福岡市東区箱崎 6-10-1（宁812-8581）

2005.11. 7 受理
人 DC 2 名), 修士課程 7 名, 学部生 3 名で, 高分子組織 体の精密構造，物性制御に関する研究を行っている.

現在，主なテーマは，精密高分子反応系の開発，界面精 密構造制御に基づく (有機/無機) ハイブリッド系の構築, 有機単分子膜・ポリマーブラシを用いた材料表面の 2 次元 構造と物性の制御, 新しい生分解性エラストマーの開発で ある. これらの研究の中で, 有機高分子薄膜の二次元微細 加工，インクジェット法による微細薄膜形成，ナノコンポ ジット創製，生分解性エラストマーのエレクトロスピニン グなどの研究が成形加工と密接に関連している.

\section{3 . 当分野の研究内容}

\section{1 精密高分子反応を利用する新規高分子材料の開発 と評価}

一般に高分子は共有結合という強固な結合により構成さ れているために, 重合反応で構造が規定されると, 特殊な 条件を除いては分子構造を変化させることは困難となる. しかしながら外部刺激により開裂する特殊な共有結合を高 分子に導入できれば，構造変化を自在に制御できるような 高分子を構築することが可能である. 高分子の反応を精密 に制御した「精密高分子反応」を行うことが可能な新しい タイプの高分子を開発している．例えば，これまでに高分 子の主鎖中に「アルコキシアミン」という骨格を導入した 高分子を合成した。アルコキシアミンは，室温では安定な 構造を有しているが，加熱により結合の一部が可逆的に解 離一付加を繰り返す。アルコキシアミン骨格を有する高分 子は，高分子主鎖中へのモノマー挿入反応が可能であり， 実際にアルコキシアミン骨格を有するポリウレタン主鎖中 へポリスチレン鎖の挿入に成功した。このようにして得ら れた高分子は精密に官能基が配列した高分子であり, 新し い高分子の合成法として有用である.

また，アルコキシアミン骨格を有するポリエステルとポ リウレタンを用いて，アルコキシアミン骨格の交換反応に 基づく，主鎖の交換反応（組み換え）を行うことにも成功 している（図1）。このような主鎖交換反応による高分子 の複合化反応は, 高分子の分子量, 成分比, ブロック化率, などを制御できる方法であり, 従来までの方法とは全く異 なるナノレベルでの複合化手法である。このような手法は, 将来的には, 高分子の精密機能変換, 精密接着反応などに 利用できる可能性が期待される. 


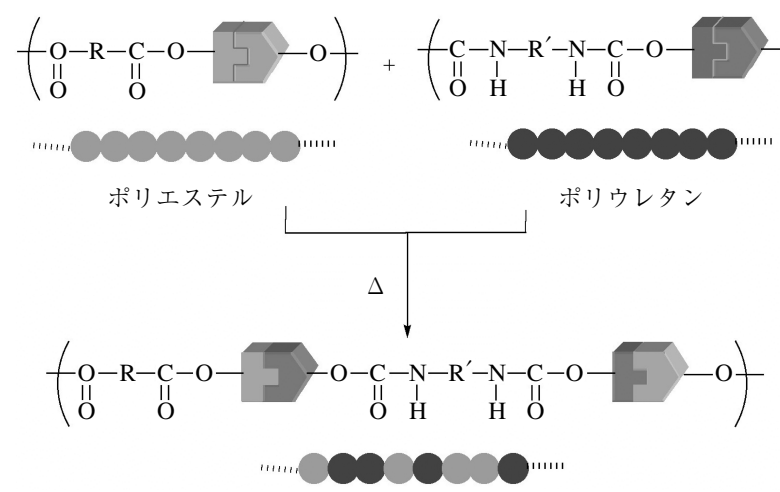

ポリエステルーポリウレタンハイブリッド

図 1 主鎖交換反応によるポリウレタンとポリエステルの ハイブリッド化

\section{2 表面開始重合を利用した固体表面の精密構造制御}

金属をはじめとするナノメートルサイズの粒子における 特異的な電気的, 磁気的, 光学的, 化学的性質が注目され, ナノテクノロジーの一分野として大きな期待が寄せられて いる。しかし，金属酸化物のように粒子間の相互作用が強 いナノ粒子の場合，容易に凝集体が形成され，ナノ粒子固 有の性質の発揮は極めて難しい. 粒子の凝集体形成を防ぐ 方法として，粒子上に高分子を吸着させ，高分子の「ひげ」 の立体的な反発により粒子を分散する手法が知られている。 この方法は単なる物理的な吸着であるため，ひげの密度， ひげの安定性は必ずしも満足できるものではない。当研究 室では金属酸化物表面とリン酸基を有する有機化合物との 特異的な相互作用に着目し，リン酸基を含む重合開始剂を 用いた表面開始重合によるナノ粒子の化学修飾を検討した。 直径が 10〜2 $25 \mathrm{~nm}$ のマグネタイト $\left(\mathrm{Fe}_{3} \mathrm{O}_{4}\right)$ および酸化チ タンにリビングラジカル重合開始骨格をもつリン酸系表面 修飾剂を化学吸着し，スチレンおよびビニルピリジンをラ ジカル重合し，長さのそろった高分子で高密度に修飾した ナノ粒子の調製に成功した（図 2).

一方，平滑な基板上への表面開始原子移動ラジカル重合 によるポリマーブラシの形成を検討した。この手法では, 1 平方ナノメートルに 0.5 分子以上のグラフト密度が達成さ れた。また親水性のモノマーを用いることにより安定な親 水性を示し，高い潤滑性，高い耐摩耗性を示す表面の形成 に成功した。またこのポリマーブラシを用いた，接着特性 の制御に関しても研究を展開している.

3.3 無機ナノチューブを用いた (有機/無機) ナノハイ ブリッド材料の構築

様々なチューブ状のナノ構造をもつ物質が注目されてい る.カーボン・ナノチューブ（CNT）に関しては国内外 で精力的な研究が行われ，電子情報デバイスなどの基盤材 料としての研究開発が進行している。一方，CNTと同様 に外径がナノメートルオーダーで，長さ数 $\mu \mathrm{m}$ の天然に 存在する無機ナノチューブである「イモゴライト」(図 3 (a)）は，CNT と異なり，透明性，表面の親水性などの特 性があるために，種々の応用展開が見込まれている.

イモゴライトは九州大学の青峰, 吉永が熊本県人吉盆地 のガラス質火山灰土「イモゴ」から，粘土鉱物であるアロ フェンの副次的産物として発見した粘土鉱物の一種で，外

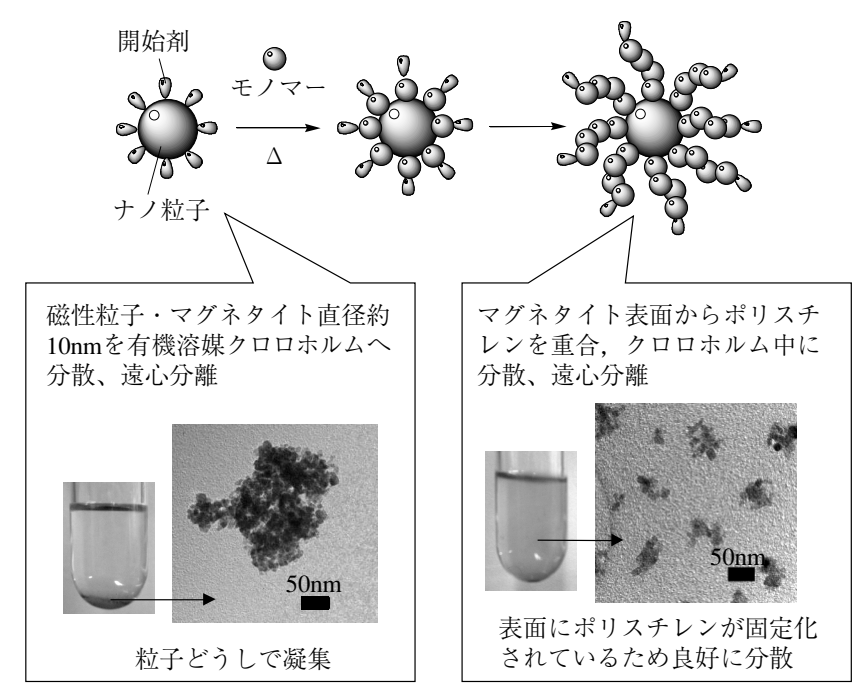

図 2 表面開始重合により化学修飾したナノ磁石の有機溶 媒への分散

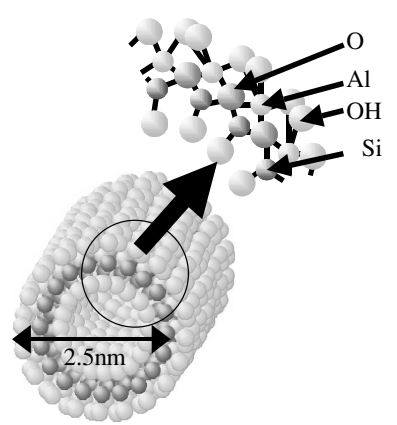

(a) イモゴライトの構造

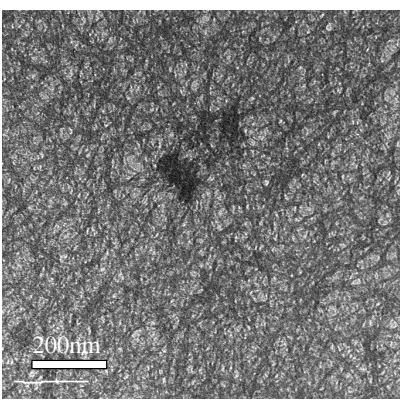

(b) イモゴライトのTEM像

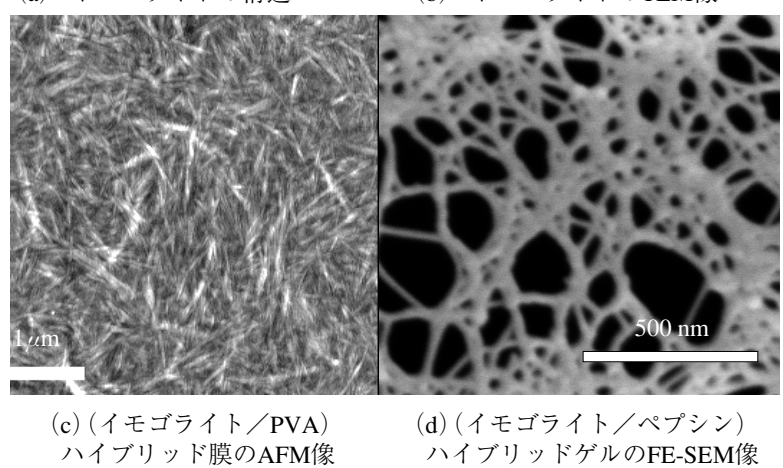

図 3 (a)イモゴライトの構造モデル, (b)イモゴライトの 透過電子顕微鏡像, (c) (PVA/その場合成イモゴラ イト）ハイブリッド膜のタッピングモード AFM 像, (d) 凍結乾燥後の（イモゴライト/ペプシン）ハイブ リッドハイドロゲルの FE-SEM 像

径 $2 \sim 2.5 \mathrm{~nm}$, 内径 $1 \mathrm{~nm}$ 以下, 長さ数百 $\mathrm{nm}$ 数 $\mu \mathrm{m}$ の特 徵的な構造をもつナノチューブ状アルミノケイ酸塩である.

イモゴライトは，風化した火山灰や軽石などに見られる 水を多量に含んだゲル状物質である。イモゴライト溶液を 基板に滴下すると, 希薄溶液からの調整した場合でも, その 高いアスペクト比のために，ナノファイバー網目構造を形 成している (図 $3(\mathrm{~b}))$. 天然に存在しているイモゴライト は表面に存在する水酸基に起因する高い親水性，ナノメー トルオーダーの形状と構造に基づく高い比表面積に起因す る高い吸着能をもつため, ガスの貯蔵媒体, 調湿材料, 速 乾性乾燥剂などの応用が期待されている。また特異的な形 


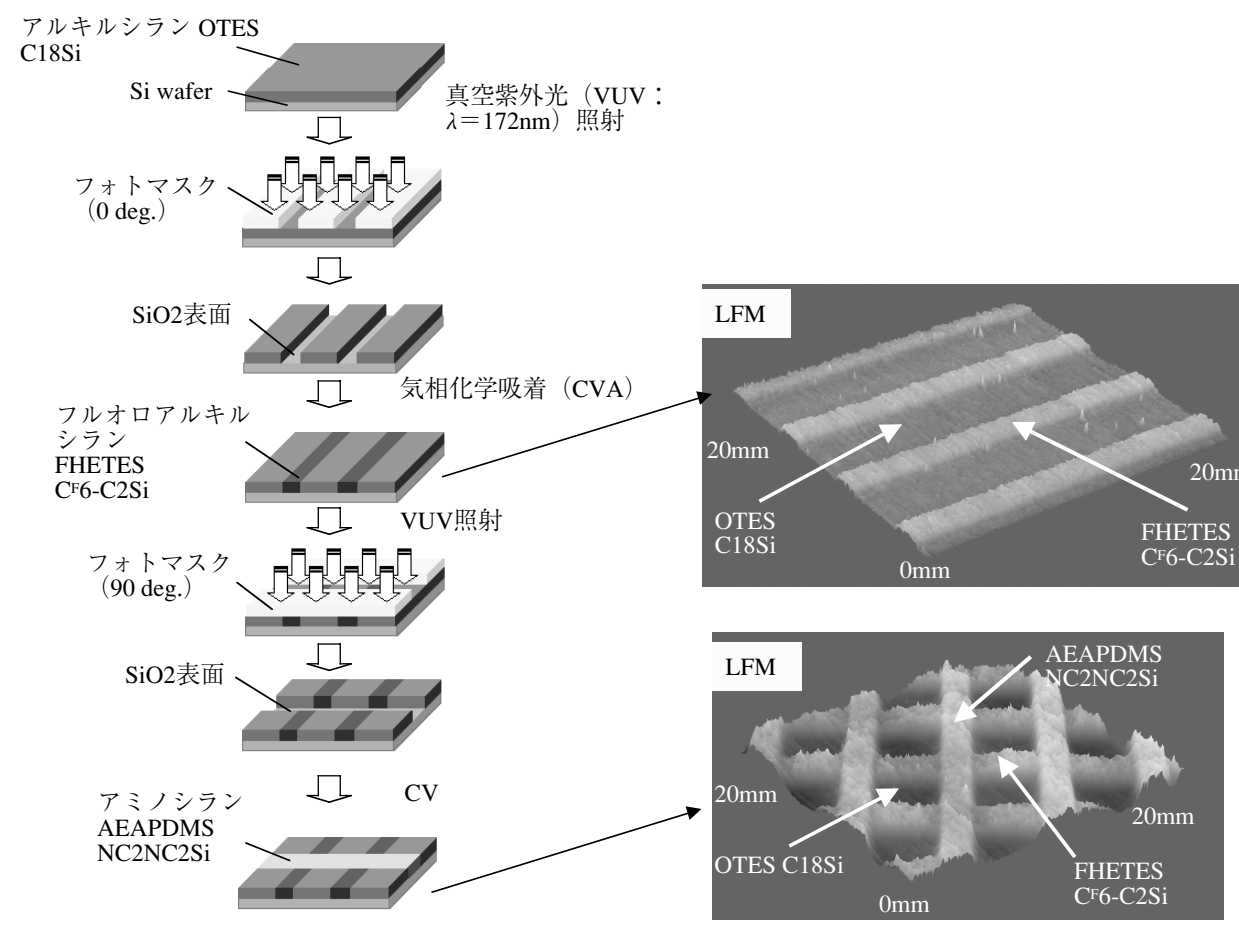

図 4 有機シラン単分子膜のパターン化

状から比較的低濃度でリオトロピック液晶を形成すること を利用した材料開発や, 高アスペクト比の形状を利用した ナノフィラーとしての応用，ナノファイバーネットワーク による酸素拡散阻害を利用した難燃性材料, 形状を制御し て配列，薄膜化したナノマテリアルとしての潜在性もある. アスペクト比と比表面積が高いイモゴライトは, 層状シ リケートと同様に強化材としての効果が十分に期待できる. 同様なナノファイバーである CNT はフィラーとして用い た場合,物性改善は確認できるが, 得られるナノコンポジッ トが黒色に着色し, 不透明性となり光学的特性が損なわれ る. 一方, イモゴライトの屈折率は一般の高分子と同程度 で, 光学的に透明であるため広範な材料への応用が可能と なる. ハイブリッド材料として応用する場合，ナノファイ バーのマトリックス高分子中における分散性が物性を支配 する．天然ゲルから精製したイモゴライト，もしくは合成 したイモゴライトは, 凍結乾燥などにより一度凝集させた 後に加工するため, 分子レベルでの再分散が非常に困難と なる.

そこで, 当研究室ではイモゴライトがマトリックス中で 分散した状態でハイブリッド材料が生成可能となる in-situ 合成法を提案した. 塩化アルミニウムとモノケイ酸を出発 原料としたイモゴライト合成反応の途中において, ポリビ ニルアルコール（PVA）水溶液を混合することで, ハイ ブリッドを調製した，天然イモゴライト，合成イモゴライ トならびにPVA とのハイブリッドについて, いずれの試 料にもイモゴライトのチューブの配列に対応する X 線回 折が観測される。

イモゴライトとPVAのハイブリッド膜をタッピング モード原子間力顕微鏡（AFM）像で観察したところ，イ モゴライトの分率が $50 \mathrm{wt} \%$ 程度であるにもかかわらず, ナノメートルサイズのファイバーが微細に分散しているこ とが確認できた(図 $3(\mathrm{c})$ ). .また,フィルム化した場合, 同
量の粉末状イモゴライトを加えて調製したPVA 複合体と 比較して高い透明性を示したことから, in-situ 合成法によ り調製したイモゴライトは高分子マトリックス中における 分散性が極めて高いことが明らかとなり，この手法が高分 子ハイブリッド化手法として有効であることが示唆された. 一方，イモゴライトはリン酸基を含むぺプシンのような たんぱく質の存在によりゲル化が促進される.ゲル中でも イモゴライトが 3 次元網目構造を形成していることが明ら かとなった（図 $3(\mathrm{~d})$ ). 膨潤状態でこの（イモゴライト／ ペプシン）ハイブリッドゲルは 30 倍の水を吸収した. ゲ ルに固定化されたペプシンは, 溶液中よりも活性は低下す るが, 加水分解特性を示した。 これは無機材料と生体分子 からなるハイブリッドゲルとして初めての例である.

\section{4 有機超薄膜の光リソグラフィー法による二次元精 密構造制御}

分子の 2 次元分布がナノメートルレベルで制御されてい る有機超薄膜は, 電子材料, マイクロマシン, 生医学材料 などの様々な工学的応用において極めて有用である. 表面 の 2 次元構造を精密制御することにより種々の複合機能の 実現が期待される.

ガラスや金属，シリコンウエハーなどの材料表面上には， 有機シランと呼ばれる低分子化合物の単分子膜 $(2 \mathrm{~nm}$ の 薄膜）が形成可能であり, しかも単分子膜が基板と水素結 合などで強く相互作用しているため, チオール系の自己組 織化単分子膜に比べて力学的, 化学的, 熱的に極めて安定 である。これらの特性に着目し, 真空紫外光 (VUV) リ ソグラフィー法による局所光分解と化学吸着による膜形成 を利用して，表面にパターンを形成し，それに基づく有機 超薄膜の機能化を検討している（図 4).

位置選択的に特性の違った表面を形成することにより材 料表面の摩擦, 摩耗あるいは濡れ特性を精密制御できる. 一方, 表面に濡れ特性の異なる成分や反応性の成分を導入 


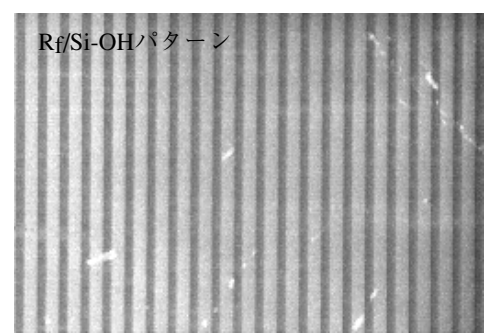

(a) FE-SEM像

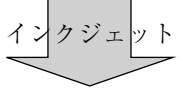

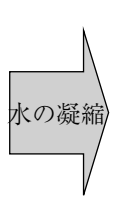

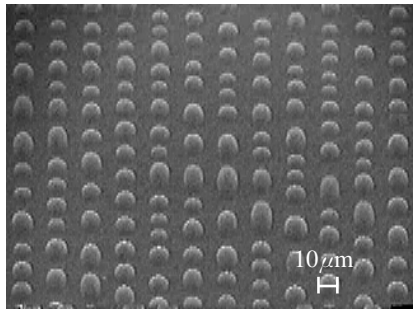

(b) 環境SEM像

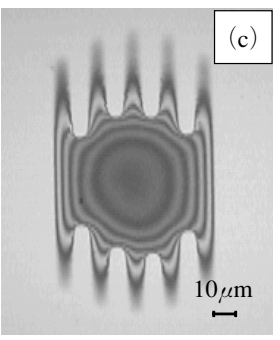

水溶性導電性高分子

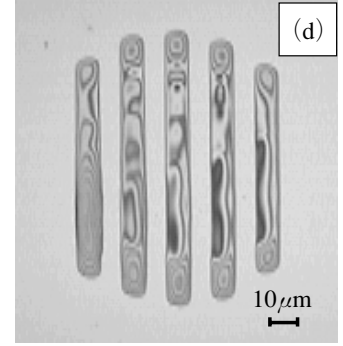

ポリスチレン

光学顕微鏡像

図 5 パターン化フルオロアルキルシラン単分子膜の (a) FE-SEM 像と, (b) 水の凝縮形態の環境 SEM 像, (c)インクジェット法により局所 製膜した高分子薄膜の光学顕微鏡像

すれば，そのパターンを反映した微粒子の固定化，液滴の 形成や高分子超薄膜の形成が可能となる.

表面エネルギーの異なる成分を配列した表面には液滴を 選択的に凝縮できる。これらはバイオチップなどの作製技 術の基盤技術として極めて重要である．フルオロアルキル シラン単分子膜を $10 \mu \mathrm{m}$ のライン幅で光分解したフルオ ロアルキルシラン $/ \mathrm{Si}-\mathrm{OH}$ パターン化単分子膜の FE-SEM 像（図 $5(\mathrm{a})$ ) とパターン化単分子膜表面への水滴の凝縮 を環境制御型 SEM で直接観察したところ，水滴はVUV 照射で単分子膜が分解した $\mathrm{Si}-\mathrm{OH}$ 領域に選択的に凝縮し, ライン方向に配列した（図 5(b))。これはフルオロアルキ ルシランが疎水性， $\mathrm{Si}-\mathrm{OH}$ が親水性であるためである.

一方，パターニングにより摩擦の方向性も制御できる. 鎖長は等しいが摩擦係数の異なるアルキルシランとフルオ ロアルキルシランのライン状パターン化単分子膜を調製し, 摩擦特性の滑り方向依存性を評価した結果, 動摩擦係数は, ラインに平行の場合に低い值を示し, 平滑な膜の場合でも 化学構造の違いによる摩擦係数の異方性が観測された。こ れは水滴がライン方向には小さな角度で滑り，ラインに垂 直方向では大きな角度で滑ることとよく対応している.

パターン化単分子膜は位置選択的な濡れ性を示すので, 有機電子材料を位置選択的に形成するための基板としても 有力である. 位置選択的な有機電子材料の作製手法として インクジェット法が挙げられる。これはノズルからインク を噴出し, 基板上へ着弾させ, 膜を形成する手法である. 基板をパターン化することにより，ノズルの直径よりも小 さな寸法の薄膜が形成可能であると予想される.

撥油性を有するフルオロアルキルシラン単分子膜/親水 性 $\mathrm{Si}-\mathrm{OH}$ パターン化単分子膜に対して, インクジェット 法により高分子薄膜を製膜した. インクはポリスチレンス
ルホン酸でドープされた導電性高分子ポリ（3,4-エチレン ジオキシチオフェン)[PEDOT/PSS] の $1.3 \mathrm{wt} \%$ 水分散 液 (c)とポリスチレン（PS）の $3 \mathrm{wt} \%$ キシレン溶液(d)を 用いた。図 5 の下側の光学顕微鏡像に示すように(c)の場 合は，パターンに対して選択的な薄膜形成は観測されな かったが，(d)の場合は，撥油性のフルオロアルキルシラ ン領域に薄膜は生成せず, $\mathrm{Si}-\mathrm{OH}$ 領域にのみ薄膜が形成 された。またインクジェットに用いるインクの表面張力が 低い方がライン状の薄膜形成に有利だった. 現在までに調 製した高分子薄膜の線幅は最小 $700 \mathrm{~nm}$ である。このよう に単分子膜の表面特性を認識した高分子薄膜を局所的に形 成することが可能となった。

\section{5 生分解性エラストマーの開発}

弾性繊維などに多用されるポリウレタンは一般に，分解 しにくく生体材料に適さないほか, 芳香族ジイソシアナー 卜に由来する発がん性成分を発生する場合がある。アミノ 酸の一種であるリジンから誘導したジイソアナートと天然 物由来のジオール(あるいはジアミン), 生分解性ポリオー ルを, 重付加反応させることで, 生分解性ポリウレタンが 合成された。ポリウレタン溶液を細管に基盤に対して高い 電圧を加えながら基板に噴霧し，繊維をたい積させる「エ レクトロスプレーデポジション」(ESD) という方法で不織 布が試作された（図 6). 従来のポリウレタンに含まれて いるジフェニルメタンジイソシアナートは, 分解性が低く, 分解されたとしても発がん性物質を出すという問題が指摘 されている. 一方, リジン由来のポリウレタンは, 微生物 によって分解され, その過程で安全性の高い成分しか発生 しない. 活性污泥中で生分解性を調べたところ，20日前 後で分解することが明らかされている. ポリウレタン特有 の弾力性は, 従来材料と同等である. ポリウレタンの構造 


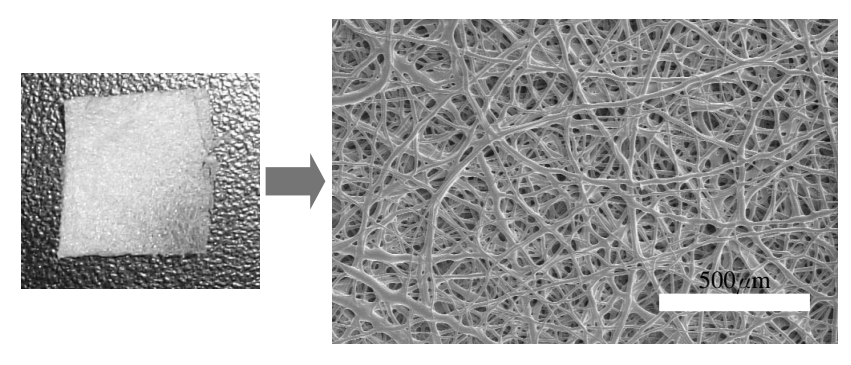

(a) エレクトロスプレー法によるミクロ不織布の形成

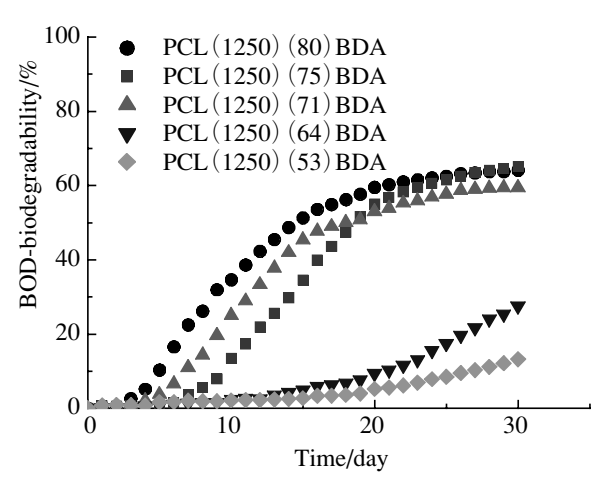

(b) 活性污泥中での生分解

図 6 (a) エレクトロスプレー法により調製した生分解性ポリウレタンのミクロ不織布と (b) 生分解性ポリウレタンの活性污泥中での分解挙動

を大型放射光施設 SPring-8 で解析し，柔らかい分子鎖か らなるソフトセグメントと分子間の結合が強いハードセグ メントの 2 つの部分が, 数 $10 \mathrm{~nm}$ のオーダーで相分離し た凝集状態になっていると優れた力学物性を示すことを明 らかにした。この生分解性ポリウレタンは生分解性樹脂の 改質剂, 農薬を徐々に放出するカプセルなど医薬関連素材 や靴底など生活関連資材への展開が期待されている.

\section{6 表面・界面ナノ構造・物性解析技術}

ここまではものづくりを中心に紹介したが，ナノスケー ルの材料の解析には新しい解析法の応用が必要不可欠であ る. 当研究室では特に, 走査フォース顕微鏡 (SFM) と 視斜角入射 $X$ 線回折 (GIXD), $X$ 線・中性子反射率を有 機高分子組織体のナノ構造の解析手段として開発・応用し ている. SFM は一般には AFM モードで表面の形態観察 に利用されているが, カンチレバーという小さな針と材料 表面の相互作用を測定しているので，その情報を界面の解 析手段として利用できる. 例えば, 摩擦力, 粘弾性, 凝着 力のようなものが挙げられる. 特に凝着力や摩擦力は表面 の官能基の種類に敏感であるので, 表面の化学構造の分布 に関するナノレベルでの情報を得ることができる，この目 的のために, カンチレバーの表面の新しい化学修飾法も開 発している。

一方，X 線回折は古くから用いられている手法であるが， 全反射を利用した GIXD 測定を行えば数ナノメートルの
膜厚の単分子膜の結晶状態や, 高分子組織体表面の結晶構 造を明らかにできる。この実験のためには放射光のような 輝度の高い線源が必要であり, 大型放射光施設 SPring-8 のビームライン「BL 13 XU」で実験を進めている. BL 13 XUでは, 従来の測定手段では解析が困難であった高分子 組織体の表面の結晶性のバルクとの違い, 気相化学吸着法 で調製した有機シラン単分子膜の結晶性，基板上での有機 半導体結晶の配向性などを明らかにしている. 最先端の機 器を用いた解析・分析は大学以外の研究施設との共同研究 が必要不可欠であり, 装置の設計などにもかかわりながら 研究を展開している.

\section{4.おわりに}

本研究室で展開している界面構造の精密な構造制御に基 づく材料の設計・開発について紹介した。最新の情報は http : //takahara.ifoc.kyushu-u.ac.jp を参照されたい.

高分子科学の分野では, 様々な機能性材料の研究が展開 されている．新しい材料の開発は精密な分子設計・合成技 術, 材料の精密特性解析技術がうまく結びついて初めて可 能となる. 本研究グループではこれら 2 つ分野の教官が 密接に協力し教育・研究を推進しており, 高分子合成と高 分子物性を基盤としてさらに新しい材料の開発に貢献して いきたいと考えている. 